\title{
'n Beoordeling van Willem Nicol se boek getiteld: Gegryp deur Christus
}

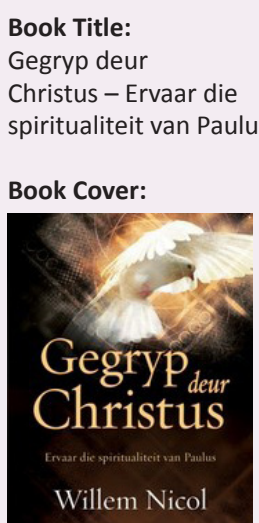

Author:

W. Nicol

ISSN:

978-1-4316-0712-9

Publisher:

Vereeniging, Christelike

Uitgewersmaatskappy, 2013 R129.95*

*Book price at time of review

Review Title:

'n Beoordeling van Willem

Nicol se boek getiteld:

Gegryp deur Christus

Reviewer:

De Wet Saaiman ${ }^{1}$

Affiliation:

${ }^{1}$ Faculty of Theology, North-West University,

Potchefstroom Campus,

South Africa

Email:

dsaaiman@isat.co.za

Postal Address:

PO Box 1627, Rant-en-Dal

1751, South Africa

How to cite this book review:

Saaiman, D., 2014, "n

Beoordeling van Willem Nicol se boek getiteld: Gegryp deur Christus', In die Skriflig/In Luce Verbi 48(1), Art. \#1807,

2 pages. http://dx.doi.

org/10.4102/ids.v48i1.1807

Read online:

Scan this $Q R$ code with your smart phone or mobile device to read online.
Nicol sê by die intrapslag van sy boek dat 'n mens op die pad van ervaring 'verstaan' nodig het en dat hy saam met die lesers moeite sal doen om 'Paulus goed en diep te verstaan'. Met hierdie woorde dek hy as ' $t$ ware die tafel vir die lesers om 'n persoonlike, Skrifgefundeerde ervaring van die leidende teenwoordigheid van die Gees in hulle lewe te kweek, sodat dit daarin sigbaar sal word. Die hoofdoel van sy boek is die lesers se ervaring (bl. 7). As skrywer is dit sy bedoeling dat lesers by daardie ervarings moet kan aansluit sodat hulle dit op hulle eie manier saam met hom kan ervaar. Ervaring het egter tyd nodig om in te sink, redeneer die skrywer. Daarom is dit nodig dat ' $n$ mens hierdie boek (en Paulus) stadig en versigtig, nadenkend en belewend moet lees.

Nicol sluit met hierdie boek aan by sy skrywe oor die spiritualiteit van Johannes. Die klem val egter hier op die spiritualiteit van Paulus; en soos die skrywer tereg sê, net op 'n groter skaal. In hierdie boek ervaar ' $n$ mens inderdaad op ' $n$ insiggewende, praktiese en verstaanbare wyse die diep teologiese waarhede aangaande Paulus se spiritualiteit.

Die boek bestaan uit 26 hoofstukke wat Skrifmeditasie, luister, gesprek en gebed gebruik om Paulus se ervaring (oor God, Christus en die Heilige Gees) op 'n spirituele vlak met die lesers te deel. Die temas wat bespreek word, is onder andere: Wie is God?; die boodskap wat alles omkeer; die tronk waaruit ons almal moet ontsnap; geloof vir die lewe; gedra deur gebed; die rykdom van God se vrede en blydskap; wyse keuses en besluite; die wonder van verbondenheid met mekaar; en eenheid met die skepping.

Elke hoofstuk word afgesluit met wenke hoe om jou spiritualiteit te verryk en met Paulus se insigte te verdiep, asook vrae gerig aan die individuele leser van die boek en bruikbare riglyne veral vir kleingroepbesprekings.

Wat my veral aangegryp het, is Nicol se verduideliking van die uitdrukking in Christus en die betekenis daarvan. Hierdie uitdrukking is volgens Nicol die kragveld wat God deur Christus geskep het. Dit is syns insiens die enigste plek waar 'n mens met God vervul kan word. Nicol se verduideliking oor ware spiritualiteit laat by 'n mens ' $n$ blywende indruk (bl. 202). Hierdie spiritualiteit mik nie soos in die geval van die Korintiërs na boontoe nie, maar ondertoe - na die naastes daar waar hulle op die oomblik is, om ook hulle vuil voete te was, na die liefde in die harde werklikheid, en ook na ' $n$ lewe in ooreenstemming met die gewonde morele beginsels. Veral in die tyd waarin ons leef, is daar 'n groot behoefte aan gesonde spiritualiteit. Soos Nicol dit verwoord, sal gesonde spiritualiteit ons nie soos konings laat lyk nie, maar soos slawe van Christus wat bereid is om te dien en te ly (bl. 203).

Wanneer Nicol vir die lesers die hart van Paulus beskryf, doen hy dit met die begrip in Christus. Sy verduideliking van die formule, in Christus, is insiggewend en van onskatbare waarde om die spiritualiteit van Paulus te verstaan. Volgens Nicol verkondig Paulus nie net dat Christus gekruisig en opgewek is nie, maar hy verstaan en verkondig die betekenis daarvan uit die $\mathrm{Ou}$ Testament. Wanneer Paulus dus die naam Christus gebruik, praat hy oor die Een wat al God se planne vir Israel, die mensdom en die wêreld vervul; die Een wat die dood oorwin het en daarmee in ' $n$ nuwe bestaan ingegaan het; wat onbeskryflike nuwe moontlikhede vir ons skep. Christus is die ewige Seun van God deur Wie die ganse heelal geskep is en elke oomblik in stand gehou word (Kol 1:16-17; bl. 104-105).

Nicol se boek is goed geskryf en spreek deurgaans van kritiese sowel as goed deurdagte denke. 'n Enkele kritiese opmerking is egter sy beskouing van die sondeleer en spesifiek die leer oor die erfsonde (bl. 172). Dit strook myns insiens glad net met die gereformeerde siening oor die erfsonde nie en kan vir oningeligte lesers met meer onsekerheid en vrae laat as wat dit werklik 'n bydrae tot die verstaan en ervaring van Paulus se spiritualiteit lewer. Ten spyte van hierdie

Copyright: (c) 2014. The Authors. Licensee: AOSIS OpenJournals. This work is licensed under the Creative Commons Attribution License. 
oorsig is Gegryp deur Christus egter deurgaans 'n verrykende ervaring wat lesers dieper in Paulus se spiritualiteit sal inlei. Soos iemand tereg opgemerk het, behoort 'n boek soos hierdie stadig gelees te word. Indien jy dit stadig lees, sal jy ook deur die boek gegryp word. Gegryp deur Christus sal jou lei om jou eie ervaring rondom Paulus se lewe te bou. Ek kan dit van harte aanbeveel vir elke predikant, kerklike leier en lidmaat wat geestelik daarna smag om deur Christus gegryp te word en wat ' $n$ behoefte daarna het om geestelik te groei. 